\title{
Children with low birth weight and low gestational age in Oslo, Norway: immigration is not the cause of increasing proportions
}

\author{
Camilla Stoltenberg, Per Magnus
}

\begin{abstract}
Study objective - To determine the influence of children born to immigrant mothers on the total proportions of low birth weight and preterm deliveries in Oslo and to explain the increases in the proportions of children with low birth weight and low gestational age since 1980-82.

Design - This was a cross sectional study based on Norwegian Medical Birth Registry data and information on mothers' country of birth from the Central Bureau of Statistics.

Setting - Oslo, Norway 1968-91.

Population - All births in Oslo between 1968 and $1991(n=146133)$.

Main results - The observed increased proportion of children with low birth weight and low gestational age born after 1980-82 is not the result of an increased proportion of children born to immigrant women. Caesarean section rates have increased dramatically and the higher proportions of children with low birth weight and gestational age may be explained by this.

Conclusions - Wide use of caesarean section probably results in more children of low birth weight and low gestational age as an iatrogenic effect. The trend in the proportion of children with low birth weight and low gestational age is not correlated to perinatal mortality after 1982 . Using proportions of low birth weight and gestational age as indicators of a nation's child health status may therefore be misleading in countries with high rates of caesarean section.
\end{abstract}

( $(\mathcal{F}$ Epidemiol Community Health 1995;49:588-593)

The proportion of children with a birth weight $<2500 \mathrm{~g}$ has increased in Norway since 1980 according to the Norwegian Medical Birth Registry. ${ }^{1}$ The increase is particularly pronounced in Oslo. ${ }^{1}$ There is a parallel increase in the proportion of children born with gestational age $<37$ weeks. No factors that can account for these observed trends have been identified yet but the higher proportion of children born to immigrant mothers has been proposed as one possible explanation. ${ }^{2}$

The primary aim of this study was to determine the influence of children born to immigrant mothers on the total proportion of low birth weight and preterm deliveries in Oslo.
The subsequent questions asked were: to what extent can changes in maternal age, parity, plurality, and frequency of caesarean section account for the increase, and what is the relationship between low birth weight and mortality?

\section{Methods}

POPULATION

This study was based on all birth certificates $(n=146133)$ issued in Oslo between 1968 and 1991 and registered in the Norwegian Medical Birth Registry.

VARIABLES

Birth weight

Birth weight was regarded as a dichotomous variable, with a low birth weight defined as $<2500 \mathrm{~g}$. Information on birth weight was missing in 430 cases (3/1000).

\section{Gestational age}

Calculation of gestational age was based on information on the date of the first day of the mother's last menstrual period and the date of birth or expulsion of the fetus. An estimate of gestational age was missing in 5442 cases (37/ 1000). Preterm delivery was defined as delivery before 37 completed weeks of gestation.

Stillborn children with a gestational age $\leqslant 28$ completed weeks and stillbirths without information on gestational age were excluded from the analysis.

The introduction of routine ultrasonography in pregnancy does not affect the recording of gestational age in the Norwegian Medical Birth Registry, since this parameter is calculated on the basis of information on the first day of the woman's last menstrual period.

\section{Mother's country of birth}

The birth registry data have been linked with data from the Norwegian Central Bureau of Statistics through a unique personal identification number for each inhabitant in Norway. These data contain information on maternal country of birth. For the purpose of this study, maternal country of birth was categorised as "Asian countries" (4.8\%), "Norway" $(87 \cdot 3 \%)$, and "other countries" $(7 \cdot 7 \%)$. In 155 cases $(0 \cdot 1 \%)$, there was no information on the maternal country of birth. Mothers born in Pakistan constitute the largest group among 
Asians $(66 \cdot 0 \%)$. Mothers born in Europe $(73 \cdot 1 \%)$ and North and Central America $(9.6 \%)$ dominate in the group labelled "other countries". All mothers with a foreign (nonNorwegian) country of birth were defined as "immigrants". For simplicity we use the terms "Norwegian", "Asian", and "other" women to describe the groups, although the Asian women and women from "other countries" may have Norwegian citizenship, and a few $(3 \cdot 1 \%)$ of the women born in Norway do have a foreign (mainly European) ethnic background.

Other explanatory variables

In addition to maternal origin, the following variables were included in the analysis: parity, maternal age, year of birth, caesarean section, and plurality.

Parity. Parity is defined by the number of prior deliveries. Those with no children before the study delivery were considered primiparous, and those with earlier deliveries multiparous.

Maternal age. Age at delivery was calculated by subtracting the mother's year of birth from the child's year of birth.

Year of birth. Year of birth of the child was from 1968 to 1991 . Year of birth is, for simplicity, categorised into 8, three-year groups.

Caesarean section. This variable includes all kinds and all indications for caesarean section. The validity of the registration in the Norwegian Medical Birth Registry has been investigated and a $3 \%$ rate of under-reporting was found. ${ }^{3}$

Plurality. Plurality was dichotomised into single and plural births.
STATISTICAL METHODS

All variables were handled as discrete variables. They were analysed by $\chi^{2}$ tests in contingency tables, Pearson correlation coefficient (r), and multiple logistic regression using SPSS for Windows. ${ }^{4}$

\section{ETHICAL APPROVAL}

The study was approved by the Norwegian Data Inspectorate and the Norwegian Board of Health.

\section{Results}

MORE IMMIGRANT MOTHERS

The proportion and absolute number of deliveries by immigrant mothers in Oslo increased between 1968-70 and 1989-91 (table 1). In $1968-70,5 \cdot 2 \%$ of all newborn children had mothers who had been born in foreign countries, whereas in 1989-91 the percentage was 21.0 . The proportion of children with mothers born in Asia increased from $0.2 \%$ to $9.9 \%$ during the study period and the proportion of mothers who were born in "other countries" rose from $5 \cdot 0 \%$ to $11 \cdot 1 \%$.

INCREASED PROPORTION OF CHILDREN WITH LOW BIRTH WEIGHT AND LOW GESTATIONAL AGE AMONG NORWEGIAN MOTHERS

A higher proportion of Asian children had a birth weight below $2500 \mathrm{~g}$ (table 2) and a gestational age below 37 weeks (table 3 ) than in the two other groups. While $5 \cdot 4 \%$ (95\% confidence interval (CI) $5 \cdot 2,5 \cdot 5)$ of Norwegian children

Table 1 Number (\%) of children born in Oslo between 1968 and 1991 in relation to the mother's country of birth

\begin{tabular}{|c|c|c|c|c|c|c|c|}
\hline \multirow[b]{2}{*}{ Period of birth } & \multicolumn{7}{|c|}{ Mother's country of birth } \\
\hline & $\begin{array}{l}\text { Asia } \\
\text { No }\end{array}$ & $(\%)$ & $\begin{array}{l}\text { Other } \\
\text { No }\end{array}$ & $(\%)$ & $\begin{array}{l}\text { Norway } \\
\text { No }\end{array}$ & $(\%)$ & $\begin{array}{l}\text { All } \\
\text { No }\end{array}$ \\
\hline $\begin{array}{l}1968-70 \\
1971-73 \\
1974-76 \\
1977-79 \\
1980-82 \\
1983-85 \\
1986-88 \\
1989-91\end{array}$ & $\begin{array}{r}37 \\
83 \\
411 \\
757 \\
869 \\
1149 \\
1649 \\
2130\end{array}$ & $\begin{array}{l}(0 \cdot 2) \\
(0 \cdot 4) \\
(2 \cdot 4) \\
(4 \cdot 7) \\
(5 \cdot 6) \\
(7 \cdot 2) \\
(8 \cdot 7) \\
(9 \cdot 9)\end{array}$ & $\begin{array}{l}1057 \\
1049 \\
1020 \\
1131 \\
1329 \\
1379 \\
1880 \\
2407\end{array}$ & $\begin{array}{c}(5 \cdot 0) \\
(5 \cdot 4) \\
(5 \cdot 9) \\
(7 \cdot 0) \\
(8 \cdot 5) \\
(8 \cdot 7) \\
(9.9) \\
(11 \cdot 1)\end{array}$ & $\begin{array}{l}20020 \\
18172 \\
15872 \\
14201 \\
13455 \\
13395 \\
15440 \\
17086\end{array}$ & $\begin{array}{l}(94 \cdot 8) \\
(94 \cdot 1) \\
(91 \cdot 7) \\
(88 \cdot 3) \\
(86 \cdot 0) \\
(84 \cdot 1) \\
(81 \cdot 4) \\
(79 \cdot 0)\end{array}$ & $\begin{array}{l}21114 \\
19304 \\
17303 \\
16089 \\
15653 \\
15923 \\
18969 \\
21623\end{array}$ \\
\hline Total & 7085 & $(4 \cdot 9)$ & 11252 & $(7 \cdot 7)$ & 127641 & $(87 \cdot 4)$ & 145978 \\
\hline
\end{tabular}

Missing observations $=155$.

Table 2 Number (\%) of children with a birth weight $<2500 \mathrm{~g}$ in relation to the mother's country of birth

\begin{tabular}{|c|c|c|c|c|c|c|c|c|}
\hline \multirow[b]{2}{*}{ Period of birth } & \multicolumn{8}{|c|}{ Mother's country of birth } \\
\hline & $\begin{array}{l}\text { Asia } \\
\text { No }\end{array}$ & $(\%)$ & $\begin{array}{l}\text { Other } \\
\text { No }\end{array}$ & $(\%)$ & $\begin{array}{l}\text { Norway } \\
\text { No }\end{array}$ & $(\%)$ & $\begin{array}{l}\text { All } \\
\text { No }\end{array}$ & $(\%)$ \\
\hline $\begin{array}{l}1968-70 \\
1971-73 \\
1974-76 \\
1977-79 \\
1980-82 \\
1983-85 \\
1986-88 \\
1989-91\end{array}$ & $\begin{array}{r}2 \\
10 \\
47 \\
63 \\
59 \\
87 \\
123 \\
159\end{array}$ & $\begin{array}{r}(5 \cdot 4) \\
(12 \cdot 2) \\
(11.5) \\
(8 \cdot 4) \\
(6 \cdot 8) \\
(7 \cdot 6) \\
(7 \cdot 5) \\
(7 \cdot 5)\end{array}$ & $\begin{array}{r}60 \\
67 \\
45 \\
48 \\
62 \\
64 \\
115 \\
129\end{array}$ & $\begin{array}{l}(5 \cdot 8) \\
(6 \cdot 5) \\
(4 \cdot 4) \\
(4 \cdot 3) \\
(4 \cdot 7) \\
(4 \cdot 6) \\
(6 \cdot 1) \\
(5 \cdot 4)\end{array}$ & $\begin{array}{r}1224 \\
1009 \\
865 \\
713 \\
533 \\
720 \\
834 \\
923\end{array}$ & $\begin{array}{l}(6 \cdot 1) \\
(5 \cdot 6) \\
(5 \cdot 5) \\
(5 \cdot 0) \\
(4 \cdot 0) \\
(5 \cdot 4) \\
(5 \cdot 4) \\
(5 \cdot 4)\end{array}$ & $\begin{array}{r}1289 \\
1086 \\
958 \\
826 \\
657 \\
871 \\
1073 \\
1211\end{array}$ & $\begin{array}{l}(6 \cdot 1) \\
(5 \cdot 6) \\
(5 \cdot 5) \\
(5 \cdot 1) \\
(4 \cdot 2) \\
(5 \cdot 5) \\
(5 \cdot 7) \\
(5 \cdot 6)\end{array}$ \\
\hline Total & 550 & $(7 \cdot 8)$ & 590 & $(5 \cdot 3)$ & 6821 & $(5 \cdot 4)$ & 7971 & $(5 \cdot 5)$ \\
\hline $\begin{array}{l}\chi^{2}(\mathrm{df}) \\
\mathrm{p} \text { value }\end{array}$ & 12 & $\begin{array}{l}(7) \\
0.09\end{array}$ & 12 & $\begin{array}{l}(7) \\
0.09\end{array}$ & 80 & $\begin{array}{l}(7) \\
<0.001\end{array}$ & 73 & $\begin{array}{l}(7) \\
<0.001\end{array}$ \\
\hline
\end{tabular}
$\%=$ Proportion (percent) of children with birth weight less than 2500 grams.
$\mathrm{df}=$ degrees of freedom. 
Table 3 Number (\%) of children with a gestational age less than 37 weeks in relation to the mother's country of birth

\begin{tabular}{|c|c|c|c|c|c|c|c|c|}
\hline \multirow[b]{2}{*}{ Period of birth } & \multicolumn{8}{|c|}{ Mother's country of birth } \\
\hline & $\begin{array}{l}\text { Asia } \\
\text { No }\end{array}$ & $(\%)$ & $\begin{array}{l}\text { Other } \\
\text { No }\end{array}$ & $(\%)$ & $\begin{array}{l}\text { Norway } \\
\text { No }\end{array}$ & $(\%)$ & $\begin{array}{l}\text { All } \\
\text { No }\end{array}$ & $(\%)$ \\
\hline $\begin{array}{l}1968-70 \\
1971-73 \\
1974-76 \\
1977-79 \\
1980-82 \\
1983-85 \\
1986-88 \\
1989-91\end{array}$ & $\begin{array}{r}3 \\
12 \\
38 \\
57 \\
64 \\
107 \\
151 \\
196\end{array}$ & $\begin{array}{r}(8.6) \\
(16.9) \\
(10.3) \\
(8.0) \\
(7.9) \\
(10.1) \\
(9.7) \\
(9.8)\end{array}$ & $\begin{array}{r}71 \\
87 \\
49 \\
73 \\
77 \\
95 \\
158 \\
176\end{array}$ & $\begin{array}{l}(7 \cdot 0) \\
(8 \cdot 6) \\
(5 \cdot 0) \\
(6 \cdot 7) \\
(6 \cdot 1) \\
(7 \cdot 3) \\
(9 \cdot 0) \\
(7 \cdot 7)\end{array}$ & $\begin{array}{r}1420 \\
1128 \\
699 \\
844 \\
653 \\
823 \\
979 \\
1150\end{array}$ & $\begin{array}{l}(7 \cdot 3) \\
(6 \cdot 3) \\
(6 \cdot 5) \\
(6 \cdot 1) \\
(5 \cdot 0) \\
(6 \cdot 4) \\
(6 \cdot 7) \\
(7 \cdot 1)\end{array}$ & $\begin{array}{r}1500 \\
1227 \\
1088 \\
977 \\
797 \\
1025 \\
1288 \\
1522\end{array}$ & $\begin{array}{l}(7 \cdot 3) \\
(6 \cdot 5) \\
(6 \cdot 5) \\
(6 \cdot 2) \\
(5 \cdot 3) \\
(6 \cdot 8) \\
(7 \cdot 2) \\
(7 \cdot 4)\end{array}$ \\
\hline Total & 628 & $(9 \cdot 5)$ & 786 & $(7 \cdot 3)$ & 7996 & $(6 \cdot 5)$ & 9424 & $(6 \cdot 7)$ \\
\hline $\begin{array}{l}\chi^{2}(\mathrm{df}) \\
\mathrm{p} \text { value }\end{array}$ & 10 & $\begin{array}{l}(7) \\
0.02\end{array}$ & 21 & $\begin{array}{l}(7) \\
<0.05\end{array}$ & 81 & $\begin{array}{l}(7) \\
<0.001\end{array}$ & 93 & $\begin{array}{l}(7) \\
<0.001\end{array}$ \\
\hline
\end{tabular}

$\mathrm{df}=$ degrees of freedom

Table 4 Parity and maternal age in relation to the mother's country of birth grouped into three year periods of birth, Oslo 1968-91

\begin{tabular}{|c|c|c|c|c|c|c|}
\hline \multirow[b]{2}{*}{ Period of birth } & \multicolumn{3}{|c|}{ Primiparous (\%) } & \multicolumn{3}{|c|}{ Maternal age $\geq 30 y(\%)$} \\
\hline & $\begin{array}{l}\text { Asia } \\
(n=7056)\end{array}$ & $\begin{array}{l}\text { Other } \\
(n=11214)\end{array}$ & $\begin{array}{l}\text { Norway } \\
(n=127 \text { 169) }\end{array}$ & $\begin{array}{l}\text { Asia } \\
(n=7078)\end{array}$ & $\begin{array}{l}\text { Other } \\
(n=11233)\end{array}$ & $\begin{array}{l}\text { Norway } \\
(n=127338)\end{array}$ \\
\hline $\begin{array}{l}1968-70 \\
1971-73 \\
1974-76 \\
1977-79 \\
1980-82 \\
1983-85 \\
1986-88 \\
1989-91\end{array}$ & $\begin{array}{l}36 \cdot 1 \\
64 \cdot 6 \\
50 \cdot 5 \\
33 \cdot 7 \\
32 \cdot 0 \\
28 \cdot 9 \\
31 \cdot 1 \\
36 \cdot 5\end{array}$ & $\begin{array}{l}46 \cdot 9 \\
53 \cdot 5 \\
50 \cdot 4 \\
52 \cdot 2 \\
47 \cdot 2 \\
48 \cdot 2 \\
51 \cdot 9 \\
49 \cdot 4\end{array}$ & $\begin{array}{l}51 \cdot 7 \\
54 \cdot 1 \\
56 \cdot 0 \\
55 \cdot 3 \\
57 \cdot 1 \\
58 \cdot 6 \\
59 \cdot 0 \\
57 \cdot 4\end{array}$ & $\begin{array}{l}36 \cdot 1 \\
25 \cdot 6 \\
21 \cdot 6 \\
26 \cdot 9 \\
31 \cdot 0 \\
34 \cdot 3 \\
38 \cdot 0 \\
38 \cdot 3\end{array}$ & $\begin{array}{l}33 \cdot 1 \\
29 \cdot 5 \\
36 \cdot 2 \\
35 \cdot 9 \\
39 \cdot 7 \\
44 \cdot 7 \\
41 \cdot 9 \\
42 \cdot 8\end{array}$ & $\begin{array}{l}22 \cdot 0 \\
19 \cdot 5 \\
21 \cdot 5 \\
28 \cdot 4 \\
30 \cdot 9 \\
35 \cdot 8 \\
39 \cdot 3 \\
44.5\end{array}$ \\
\hline Total & $34 \cdot 3$ & 49.9 & 55.9 & $34 \cdot 3$ & $39 \cdot 1$ & $29 \cdot 8$ \\
\hline
\end{tabular}

and $5 \cdot 3 \%(95 \%$ CI $4 \cdot 9,5 \cdot 7)$ of children born to mothers from "other" countries had a birth weight $<2500 \mathrm{~g}, 7 \cdot 8 \%$ (95\% CI $7 \cdot 2,8.4)$ of Asian children had a low birth weight.

There was a gradual fall in the proportion of children with a birth weight $<2500 \mathrm{~g}$ between 1968-70 and 1980-82, followed by an increase from $4.2 \%(95 \%$ CI $3.9,4.5)$ in $1980-82$ to $5.6 \%(95 \%$ CI $5 \cdot 3,5 \cdot 9)$ in $1989-91$ (table 2 ). This pattern was found in the total population and among children of Norwegian women, where the increase was from $4.0 \%(95 \% \mathrm{CI}$ $3 \cdot 6,4 \cdot 3)$ to $5 \cdot 4 \%(95 \%$ CI $5 \cdot 1,5 \cdot 8)$ between $1980-82$ and $1989-91 \quad\left(\chi^{2}=44, \quad \mathrm{df}=3\right.$, $\mathrm{p}<0.001)$. Among children of women who were born in "other" and in Asian countries, the same tendency was present but did not reach statistical significance.

When analysing gestational age, a similar pattern appeared (table 3 ). In the rest of the article we present results for low birth weight only, since the changes in proportions of children with low birth weight and low gestational age follow each other, and relate in the same way to the confounding and explanatory variables handled in this study.

The observed changes in the proportion of children with low birth weight in the total population were found in the subgroup of children born to Norwegian mothers. Accordingly, subsequent analysis will focus on this group.

PARITY AND MATERNAL AGE

Among Norwegian women the proportion of primiparous mothers increased from $51.7 \%$ $(95 \%$ CI $51 \cdot 1,52.4)$ in $1968-70$ to $57.4 \%$ $(95 \%$ CI $56 \cdot 7,58 \cdot 2)$ in $1989-91$, but it stayed relatively stable between $1980-82$ and 1989-
91, varying between $57 \%$ and $59 \%$ (table 4 ). The proportion of mothers who were 30 years or older increased from $22 \%$ to $44.5 \%$, and the proportion of primiparous mothers who were 30 years or older increased from $9.5 \%$ to $29.8 \%$. The changes in the proportion of primiparous births did not show clear patterns for the two other groups, while the tendency towards higher maternal age was similar to that in the Norwegian population, although not as evident.

\section{CAESAREAN SECTION AND PLURALITY}

There was a dramatic shift upwards in the rate of caesarean section in all the three groups (table 5). Among the Norwegian women the rate was $2 \cdot 1 \%$ in $1968-70$ and $15.2 \%$ in 1989 91. The rates of caesarean section were of the same magnitude in the two other groups in the latter periods.

The rate of multiple births did not increase between 1968-70 and 1989-91 among Norwegian mothers. Rates of plurality changed over time in a pattern similar to that of low birth weight and low gestational age, with a slight decrease between 1968-70 and 1980-82, and an increase thereafter. In the two other groups the changes over time did not show a clear trend.

CAESAREAN SECTION AND LOW BIRTH WEIGHT When children delivered by caesarean section were excluded from the analysis no persisting increase in the proportion of children with low birth weight was seen in the three year periods from 1980-82 (table 6). The proportions of low birthweight Norwegian children were $3 \cdot 1$ 
Table 5 Caesarean section and multiple births in relation to the mother's country of birth grouped into three year periods of birth, Oslo 1968-91

\begin{tabular}{|c|c|c|c|c|c|c|}
\hline \multirow[b]{2}{*}{ Period of birth } & \multicolumn{3}{|c|}{ Caesarean section (\%) } & \multicolumn{3}{|c|}{ All multiple births (twins, triplets etc) (\%) } \\
\hline & $\begin{array}{l}\text { Asia } \\
(n=7078)\end{array}$ & $\begin{array}{l}\text { Other } \\
(n=11233)\end{array}$ & $\begin{array}{l}\text { Norway } \\
(n=127 \text { 338) }\end{array}$ & $\begin{array}{l}\text { Asia } \\
(n=7078)\end{array}$ & $\begin{array}{l}\text { Other } \\
(n=11233)\end{array}$ & $\begin{array}{l}\text { Norway } \\
(n=127338)\end{array}$ \\
\hline $\begin{array}{l}1968-70 \\
1971-73 \\
1974-76 \\
1977-79 \\
1980-82 \\
1983-85 \\
1986-88 \\
1989-91\end{array}$ & $\begin{array}{r}2 \cdot 8 \\
6 \cdot 1 \\
7 \cdot 8 \\
7 \cdot 2 \\
11 \cdot 6 \\
15 \cdot 0 \\
15 \cdot 7 \\
15 \cdot 4\end{array}$ & $\begin{array}{r}3.0 \\
3.2 \\
5.9 \\
9.2 \\
12.2 \\
13.7 \\
16.8 \\
15.8\end{array}$ & $\begin{array}{r}2 \cdot 1 \\
3 \cdot 4 \\
6 \cdot 2 \\
9 \cdot 0 \\
10 \cdot 3 \\
13 \cdot 4 \\
15 \cdot 3 \\
15 \cdot 2\end{array}$ & $\begin{array}{l}0 \\
0 \\
0 \cdot 5 \\
1 \cdot 9 \\
1 \cdot 6 \\
1 \cdot 8 \\
2 \cdot 1 \\
1 \cdot 2\end{array}$ & $\begin{array}{l}1 \cdot 6 \\
1.9 \\
2 \cdot 4 \\
2 \cdot 0 \\
1.5 \\
1.5 \\
3 \cdot 0 \\
2 \cdot 3\end{array}$ & $\begin{array}{l}2 \cdot 2 \\
1 \cdot 9 \\
2 \cdot 0 \\
1.9 \\
1 \cdot 8 \\
2 \cdot 1 \\
2 \cdot 3 \\
2 \cdot 5\end{array}$ \\
\hline Total & $13 \cdot 4$ & $11 \cdot 4$ & $9 \cdot 0$ & $1 \cdot 6$ & $2 \cdot 1$ & $2 \cdot 1$ \\
\hline
\end{tabular}

$(95 \%$ CI $2 \cdot 8,3 \cdot 4)$ in $1980-82,3.7(95 \% \mathrm{CI}$ $3 \cdot 4-4 \cdot 0)$ in $1983-85,3 \cdot 3(95 \%$ CI $3 \cdot 0-3 \cdot 6)$ in 1986-88, and $3.0(95 \%$ CI 2.8-3.3) in 1989-91.

There were changes in the proportion of Norwegian children of low birth weight among those delivered by caesarean section, with a decrease from $16.6(95 \%$ CI 13.0, 20.2) in $1968-70$ to $10.5 \%(95 \%$ CI $8.0,12.9)$ in 1970 72 , followed by an increase from $11.8(95 \%$ CI $10 \cdot 1,13.5)$ in $1980-82$ to $18.7(95 \% \mathrm{CI}$ $17 \cdot 2,20 \cdot 3$ ) in 1989-91 (table 6). In the Norwegian group of low birthweight children, $6 \cdot 1 \%$ were delivered by caesarean section in 1968-70 and $52.5 \%$ in $1989-91$.

RISK OF LOW BIRTH WEIGHT AND LOW GESTATIONAL AGE

Crude and adjusted odds ratios for the risk of delivering a child with a birth weight of $<2500 \mathrm{~g}$

Table 6 Proportion (\%) of children with a birth weight $<2500 \mathrm{~g}$ in relation to year of birth and caesarean section born to Norwegian women in Oslo, 1968-91

\begin{tabular}{lll}
\hline Period of birth & Vaginal delivery & Caesarean section \\
\hline $1968-70$ & $5 \cdot 4$ & $16 \cdot 6$ \\
$1971-73$ & $5 \cdot 0$ & $10 \cdot 5$ \\
$1974-76$ & $4 \cdot 6$ & $11 \cdot 1$ \\
$1977-79$ & $3 \cdot 9$ & $12 \cdot 3$ \\
$1980-82$ & $3 \cdot 1$ & $11 \cdot 8$ \\
$1983-85$ & $3 \cdot 7$ & $16 \cdot 3$ \\
$1986-88$ & $3 \cdot 3$ & $16 \cdot 9$ \\
$1989-91$ & $3 \cdot 0$ & $18 \cdot 7$ \\
All & $4 \cdot 1$ & $15 \cdot 3$ \\
\hline
\end{tabular}

are shown according to the mother's country of birth, parity, maternal age, year of birth, caesarean section, and plurality in table 7 . The crude odds ratio for the period $1980-82$ is significantly lower than that for each of the subsequent periods, while the latter periods are not different from each other. However, the adjusted odds ratios for the periods 1983-85, 1986-88 and 1989-91 are close to the odds ratio for $1980-82$.

This reduction in adjusted odds ratios is not apparent if caesarean section is omitted from the analysis. In that case the adjusted odds ratios for all the three later periods are close to the crude odds ratios with values of 0.9 .

Mother's country of birth, parity, maternal age, and plurality all have significant effects on the risk of delivering a low birthweight child, but do not affect the secular changes in risk, when they are included separately in the multivariate analysis.

The same results occur when this analysis is repeated with low gestational age as the dependent variable.

\section{MORTALITY}

The perinatal mortality in the Norwegian group decreased throughout the whole period both in low and normal birthweight children (table 8 ). What we have chosen to call "postperinatal" mortality, designating death from day 7 through

Table 7 Logistic regression analysis with low birth weight $(<2500 \mathrm{~g})$ as the outcome and maternal age, parity, year of birth, caesarean section, and plurality as explanatory variables

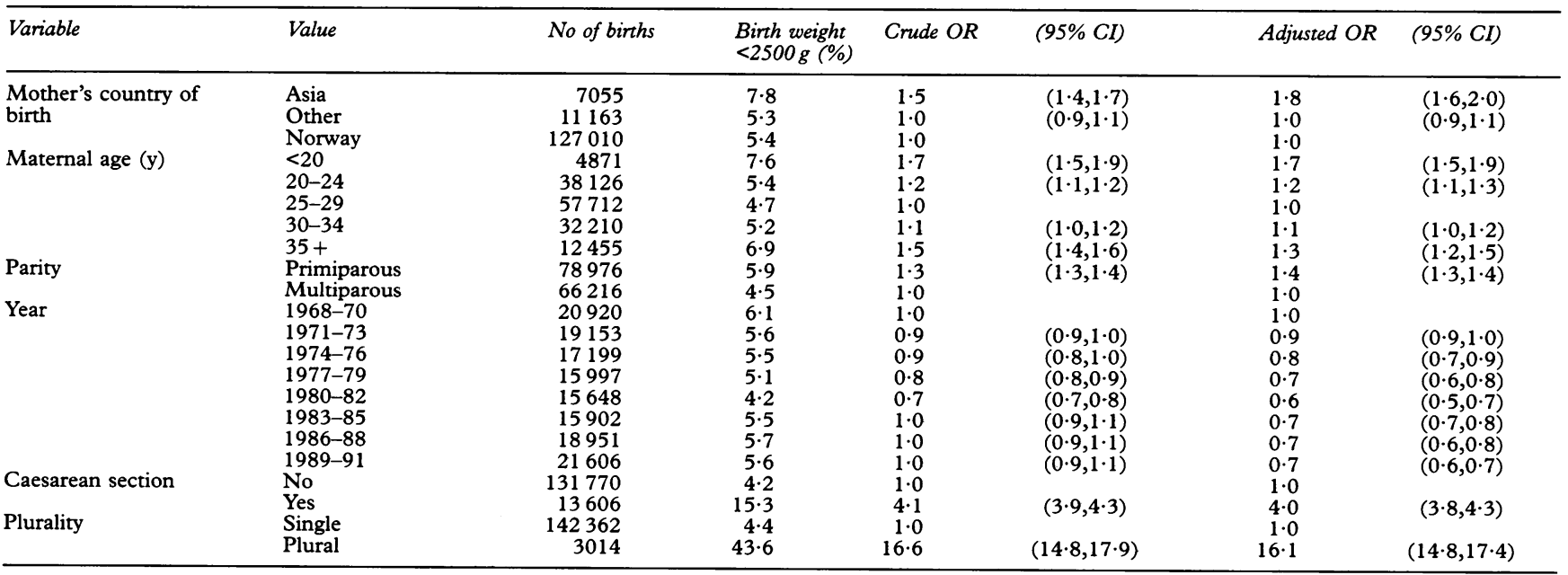

$\mathrm{OR}=$ odds ratio, $\mathrm{CI}=$ confidence interval. 
Table 8 Perinatal and "postperinatal" mortality per 1000 births (95\% confidence interval) in relation to birth weight among children of Norwegian women; Oslo 1968-91

\begin{tabular}{|c|c|c|c|c|c|c|}
\hline \multirow[b]{2}{*}{ Period of birth } & \multicolumn{3}{|c|}{ Perinatal mortality (stillbirth-6d) } & \multicolumn{3}{|c|}{ "Postperinatal" mortality $(7 d-1 y)$} \\
\hline & All & $\begin{array}{l}\text { Birth weight } \\
<2500 \mathrm{~g}\end{array}$ & $\begin{array}{l}\text { Birth weight } \\
>=2500 \mathrm{~g}\end{array}$ & All & $\begin{array}{l}\text { Birth weight } \\
<2500 \mathrm{~g}\end{array}$ & $\begin{array}{l}\text { Birth weight } \\
>=2500 \mathrm{~g}\end{array}$ \\
\hline $1968-70$ & $\begin{array}{l}20 \\
(18,22)\end{array}$ & $\begin{array}{l}245 \\
(220,271)\end{array}$ & $\begin{array}{l}6 \\
(5,7)\end{array}$ & $\begin{array}{l}4 \\
(3,5)\end{array}$ & $\begin{array}{l}28 \\
(19,39)\end{array}$ & $\begin{array}{l}3 \\
(2,4)\end{array}$ \\
\hline $1971-73$ & $\begin{array}{l}17 \\
(15,18)\end{array}$ & $\begin{array}{l}197 \\
(172,223)\end{array}$ & $\begin{array}{l}6 \\
(5,8)\end{array}$ & $\begin{array}{l}4 \\
(3,5)\end{array}$ & $\begin{array}{l}17 \\
(10,27)\end{array}$ & $\begin{array}{l}3 \\
(2,4)\end{array}$ \\
\hline $1974-76$ & $\begin{array}{l}13 \\
(11,15)\end{array}$ & $\begin{array}{l}173 \\
(147,199)\end{array}$ & & $\begin{array}{l}5 \\
(4,6)\end{array}$ & $\begin{array}{l}30 \\
(20,45)\end{array}$ & $\begin{array}{l}3 \\
(2,4)\end{array}$ \\
\hline 1977-79 & $\begin{array}{l}12 \\
(10,14)\end{array}$ & $\begin{array}{l}144 \\
(117,170)\end{array}$ & & $(3,5)$ & $\begin{array}{l}29 \\
(18,45)\end{array}$ & $(2,4)$ \\
\hline $1980-82$ & $\begin{array}{l}9 \\
(7,10)\end{array}$ & $\begin{array}{l}143 \\
(113,172)\end{array}$ & $\begin{array}{l}3 \\
(2,5)\end{array}$ & & $\begin{array}{l}13 \\
(5,27)\end{array}$ & $\begin{array}{l}3 \\
(2,4)\end{array}$ \\
\hline $1983-85$ & $\begin{array}{l}10 \\
(8,11)\end{array}$ & $\begin{array}{l}135 \\
(110,160)\end{array}$ & $(1,3)$ & $\begin{array}{l}4 \\
(3,5)\end{array}$ & $\begin{array}{l}17 \\
(9,29)\end{array}$ & $\begin{array}{l}3 \\
(2,4)\end{array}$ \\
\hline $1986-88$ & $\begin{array}{l}8 \\
(6,9)\end{array}$ & $\begin{array}{l}88 \\
(69,109)\end{array}$ & $\begin{array}{l}3 \\
(2,3)\end{array}$ & $\begin{array}{l}4 \\
(3,5)\end{array}$ & $\begin{array}{l}28 \\
(18,41)\end{array}$ & $\begin{array}{l}3 \\
(2,4)\end{array}$ \\
\hline 1989-91 & $(6,9)$ & $\begin{array}{l}93 \\
(75,114)\end{array}$ & $(2,3)$ & $(2,4)$ & $\begin{array}{l}18 \\
(11,29)\end{array}$ & $\begin{array}{l}2 \\
(2,3)\end{array}$ \\
\hline All & $\begin{array}{l}12 \\
(12,13)\end{array}$ & $\begin{array}{l}157 \\
(148,166)\end{array}$ & $\begin{array}{l}4 \\
(4,5)\end{array}$ & $\begin{array}{l}4 \\
(4,4)\end{array}$ & $\begin{array}{l}23 \\
(19,27)\end{array}$ & $\begin{array}{l}3 \\
(3,3)\end{array}$ \\
\hline
\end{tabular}

the first year of life, did not change. Both the proportion of children with a low birth weight and perinatal mortality fell between 1968-70 and 1980-82, although perinatal mortality fell more rapidly. The correlation between perinatal mortality and the proportion of children with a low birth weight was strong and positive in this period $(r=0.8, p<0.001)$. After 1980 82 , low birth weight and perinatal mortality did not continue to follow each other ( $r=$ $-0.06, p=0.9)$. The proportion of children with a low birth weight increased to a stable level from 1983-85, and the perinatal mortality rate continued to fall. The figure illustrates this for children of Norwegian women, with proportions and rates relative to the values in 1968-70.

\section{Discussion}

The observed increase in the proportions of children with low birth weight and low gestational age in Oslo since 1980 is not due to the increase in the proportion of immigrant women who have delivered children in Oslo. An in-

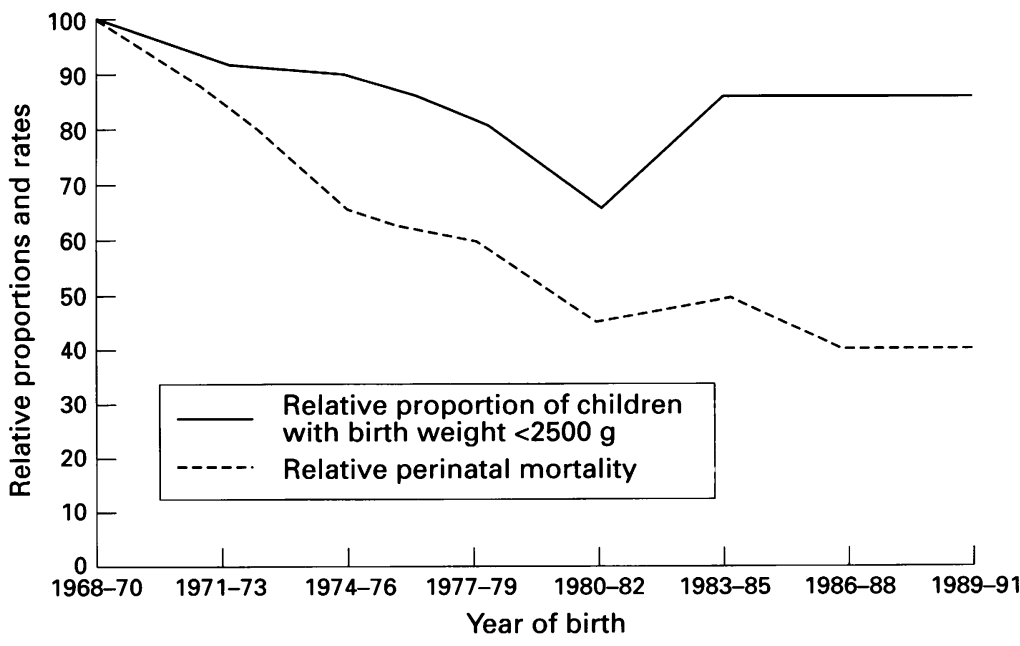

Relative proportions of children with birthweight $<2500 \mathrm{~g}$ and perinatal mortality between 1968-70 and 1989-91. From 1968 to 1982 there was a strong positive correlation between the proportion of children with birth weight $<2500 \mathrm{~g}$ and perinatal mortality among Norwegian children in Oslo. After 1982 there was no correlation between the two parameters. crease in caesarean section as the mode of delivery seems to be the explanation for these changes.

This is the first study which has considered the effect that immigrant mothers have on birth outcome in the Norwegian national statistics. It is also the first study which has analysed possible causes and consequences of the increase in the proportions of children with low birth weight and low gestational age in Norway since the early 1980 s.

The study covered all newborn children in Oslo in the period 1968-91. There is no doubt that the observed increases in the proportions of children with low birth weight and low gestational age are real: the question is - what are the causes and their biological and clinical consequences?

\section{MMIGRANTS}

The question this study set out to answer is solved in a simple stratified analysis showing that the changes in proportions of low birth weight and preterm children are parallel and almost identical in the Norwegian population and in the total population (tables 2 and 3 ). Oslo has a higher proportion of immigrant births than any other region in Norway. The tendency towards a higher proportion of low birthweight and preterm children is seen all over the country, but it is more pronounced in Oslo. ${ }^{1}$ Oslo also has a higher caesarean section rate than all other Norwegian regions, ${ }^{6}$ but this rate is not different in the three groups studied after 1982.

TRENDS IN OTHER COUNTRIES

The Nordic Medico-Statistical Committee (NOMESCO) has expressed concern about the changes in birth weight and gestational age, ${ }^{2}$ and since parallel increases have been found in other countries such as Sweden ${ }^{2}$ and the USA, ${ }^{5}$ there is interest in searching for causes.

NOMESCO reported that there had been an increase in the observed proportion of low birthweight children (among all births weighing $\geqslant 1000 \mathrm{~g}$ ) throughout the 1980 s in Finland, 
Sweden, and particularly in Norway. ${ }^{2}$ In Sweden and, again particularly in Norway, the proportion of children with a gestational age less than 37 weeks increased during the same period. $^{2}$

Data from other countries are more difficult to compare with the Nordic data. A report from Scotland for the period 1975-92 and one from England and Wales for the period 1983-89, however, show that the proportions of very low birthweight infants $(<1500 \mathrm{~g})$ increased in the periods described. ${ }^{7}$ In the USA there was an increase in the proportion of children with a low birth weight between 1979 and $1992 .{ }^{5}$

\section{CAESAREAN SECTION}

As shown in this study, and as reported elsewhere, ${ }^{36}$ the caesarean section rate has increased considerably. In addition, the proportion of babies of low birth weight has increased since 1980 among children delivered by caesarean section. As can be seen from both the stratified analysis and the multivariate logistic regression, there is no secular increase in low birth weight after 1980-82 when the caesarean section rate is controlled for. The decrease seen before 1980-82 persists, indicating that the factors causing this trend are different from those leading to the subsequent increase.

\section{IATROGENIC EFFECT}

The reason for the increase in the proportion of low birth weight children is not obvious, although it may be explained by the increased caesarean section rate in our analysis. The increase in the caesarean section rate was dramatic among all children with a birth weight $<2500 \mathrm{~g}$. There is a strong negative correlation between birth weight and both the caesarean section rate and the caesarean section rate increase over time. ${ }^{6}$ This may reflect an iatrogenic effect or a situation in which there is a combination of more fetuses at risk of becoming low birthweight children and an increased chance of these children of being delivered by caesarean section.

Most probably it is mainly an iatrogenic effect, in the sense that the increase in low birth weight is produced by a high caesarean section rate. It seems probable that the indications for caesarean section were changed, widened, or were implemented differently around 1983. An argument for this view is the new relationship between the proportions of low birthweight children and perinatal mortality.

\section{LOW BIRTH WEIGHT AND GESTATIONAL AGE AS} INDICATORS OF HEALTH AND MORTALITY Birth weight and gestational age are considered to be powerful predictors of infant survival, and are widely used as indicators of child health, and even of the future health of the general population and the quality of health services. ${ }^{27}$ It may be that the proportion of low birthweight neonates $(<2500 \mathrm{~g})$ is an appropriate and practical measure in populations with a high child morbidity and mortality.

Whether the increase in the proportions of children with low birth weight and low gestational age is important or not, the importance of birth weight as an indicator of morbidity and mortality has to be considered. Until 1982, the relationship between birth weight and perinatal and "postperinatal" mortality was close (table 7, figure). There was a continuous decline in the proportion of children with low birth weight associated with a decline in mortality. Since 1982 the increase in the proportion of children with low birth weight and low gestational age, however, has not been followed by an increase in mortality. In societies with, by all historical and international comparisons, very low child morbidity and mortality and very low proportions of births $<2500 \mathrm{~g}$ and 37 weeks of gestational age, it may be an inadequate tool for epidemiological surveillance. Changes in the proportion of children with low birth weight now reflect primarily a more advanced and agressive medical knowledge and technology which makes it possible for more women to become mothers, and more children to survive. The results represent an argument against using the proportion of children with low birth weight as an epidemiological measure in Norway and probably in other countries where birth weight, gestational age, and mortality are no longer associated in the way they have been, and where caesarean section rates are high.

\section{CONCLUSION}

Immigration is not the cause of higher proportions of children with low birth weight and low gestational age in Oslo since 1980. Caesarean section rates have increased dramatically since 1968, and since 1982 there have been higher proportions of low birthweight and low gestational age children among those who are delivered by caesarean section indicating that the increase in low birth weight and gestational age is primarily an iatrogenic effect. Perinatal mortality was strongly correlated with the proportions of children with low birth weight and low gestational age from 1968 to 1982 . After 1982 there was no correlation between the two parameters. Using proportions of children with low birth weight and gestational age as indicators of health may therefore be misleading in countries where caesarean section rates are high.

1 Medical Birth Registry of Norway. Annual report 1992. Bergen: University of Bergen, Norway 1994

2 Nielsen J, ed. Births and infant mortality in the Nordic countries. Copenhagen: Nordic Medico-Statistical Committee (NOMESCO), 1993:39.

3 Borthen I, Lossius P, Skjærven R, Bergsiø P. Changes in frequency and indications for caesarean section in Norway frequency and indications for caesarean section in Norway 4 SPSS base system reference guide. Release 6.0. Chicago: SPSS Inc 1993 .

5 Wegman ME. Annual summary of vital statistics 1992. Pediatrics 1993;92(6):743-54

6 Bergsiø P, Borthen I, Daltveit AK. Operative delivery in Norway 1970-1990 Trend analysis (in Norwegian). Tidsskr Nor Lagefor 1993;113(10):1206-11.

7 Power C. National trends in birth weight: implications for future adult disease. $B M \mathcal{F}$ 1994;308:1270-1 